\title{
Seroprevalence of Toxoplasma gondii in free-living European mouflon (Ovis orientalis musimon) hunted in central Germany
}

\author{
Mike Heddergott ${ }^{1, *}$, Natalia Osten-Sacken ${ }^{1,2}$, Peter Steinbach ${ }^{3}$, and Alain C. Frantz ${ }^{1, *}$ \\ ${ }^{1}$ Musée National d'Histoire Naturelle, 2160 Luxembourg, Luxembourg \\ ${ }^{2}$ Fondation Faune Flore, 2160 Luxembourg, Luxembourg \\ ${ }^{3}$ University of Göttingen, Faculty of Chemistry, 37077 Göttingen, Germany
}

Received 26 January 2018, Accepted 7 March 2018, Published online 10 April 2018

\begin{abstract}
Despite increasing consumption of mouflon (Ovis orientalis musimon) meat in Germany, there is currently no surveillance of Toxoplasma gondii infection in populations of these animals and generally little knowledge about the prevalence of this protozoan in German wild ungulates. Between 2011 and 2015, we collected 138 blood samples from a free-living mouflon population in central German and tested sera for the presence of T.gondii antibodies using a modified agglutination test (MAT, cut-off 1:20). Antibodies were detected in 31 of the 138 samples $(22.46 \%)$. There was a significant difference in seroprevalence between the different age classes, with antibodies to T. gondii more frequent in adults. In contrast, there was no significant difference in seroprevalence depending on sex and year of sample collection. Game meat is frequently consumed as raw or undercooked meat and may therefore represent a potential source of human infection with T. gondii.
\end{abstract}

Keywords: Toxoplasma gondii, seroprevalence, mouflon, wildlife, MAT, central Germany

\begin{abstract}
Résumé - Séroprévalence de Toxoplasma gondii chez le mouflon européen (Ovis orientalis musimon) vivant en liberté et chassé en Allemagne centrale. Malgré une consommation en augmentation de viande de mouflon (Ovis orientalis musimon) en Allemagne, il n'existe actuellement aucune surveillance de l'infection par Toxoplasma gondii dans les populations de ces animaux et généralement peu de connaissances sur la prévalence de ce protozoaire chez les ongulés sauvages allemands. Entre 2011 et 2015, nous avons prélevé 138 échantillons de sang d'une population de mouflons vivant en liberté en Allemagne centrale et testé des sérums pour détecter la présence d'anticorps contre T.gondii en utilisant un test d'agglutination modifié (MAT, seuil de 1:20). Des anticorps ont été détectés dans 31 des 138 échantillons $(22,46 \%)$. Il y avait une différence significative de séroprévalence entre les différentes classes d'âge, avec des anticorps contre T. gondii plus fréquents chez les adultes. En revanche, il n'y avait pas de différence significative de séroprévalence selon le sexe et l'année de prélèvement des échantillons. Le gibier est fréquemment consommé sous forme de viande crue ou insuffisamment cuite et peut donc représenter une source potentielle d'infection humaine par T.gondii.
\end{abstract}

\section{Introduction}

Toxoplasma gondii is a ubiquitous apicomplexan parasite of warm-blooded animals and humans [7]. Cats, which are the only known definitive host, shed unsporulated oocysts into environment [6]. Humans and wildlife can become infected by ingesting raw or undercooked meat with T.gondii tissue cysts or by consuming food or drink contaminated with oocysts $[7,16]$. T. gondii infection can be common in domesticated and wild animals intended for human consumption and the European Food Safety

\footnotetext{
*Corresponding authors: alain.frantz@mnhn.lu; mike-heddergott@web.de
}

Authority (EFSA) has recommended the surveillance and monitoring of toxoplasmosis in humans, animals and foodstuffs [9].

The mouflon (Ovis orientalis musimon) is becoming an important game species in Germany. According to the German Hunting Federation (DJV), the annual hunting bag increased from around 6000 animals in the early 2000's to around 8000 animals from 2015 onwards (www.jagdver band.de). Despite the concurrent increase in consumption of mouflon meat, there is currently no surveillance of T. gondii infection in populations of these animals and little knowledge about the prevalence of the protozoan in German wild ungulates generally $[19,23]$.

Here, we aim to assess the seroprevalence of T. gondii in a free-living German population of mouflon, 
Table 1. Seroprevalence of Toxoplasma gondii in mouflon by sex, age and collection year.

\begin{tabular}{|c|c|c|c|c|c|c|}
\hline Variable & Category & No. tested & No. positive & Prevalence in \% $(95 \% \mathrm{CI})$ & $p$-value & OR $(95 \% \mathrm{CI})$ \\
\hline \multirow[t]{2}{*}{ Sex } & Male & 76 & 19 & $25.00(15.04-34.96)$ & 0.429 & Reference \\
\hline & Female & 62 & 12 & $19.35(9.24-29.47)$ & & $0.72(0.32-1.63)$ \\
\hline \multirow[t]{3}{*}{ Age } & $\leq 1$ year & 36 & 5 & $13.89(2.02-25.76)$ & 0.002 & Reference \\
\hline & 1-2 year & 61 & 9 & $14.75(5.60-23.91)$ & & $1.07(0.33-3.49)$ \\
\hline & $\geq 2$ year & 41 & 17 & $41.46(25.72-57.21)$ & & $4.39(1.42-13.60)$ \\
\hline \multirow[t]{5}{*}{ Collection year } & 2011 & 16 & 4 & $25.00(1.17-48.83)$ & 0.967 & Reference \\
\hline & 2012 & 31 & 6 & $19.35(4.62-34.09)$ & & $0.72(0.17-3.04)$ \\
\hline & 2013 & 37 & 9 & $24.32(9.82-38.83)$ & & $0.96(0.25-3.75)$ \\
\hline & 2014 & 28 & 7 & $25.00(7.90-42.10)$ & & $1.00(0.24-4.13)$ \\
\hline & 2015 & 26 & 5 & $19.23(3.00-35.46)$ & & $0.71(0.16-3.18)$ \\
\hline Total & & 138 & 31 & $22.46(15.41-29.51)$ & & \\
\hline
\end{tabular}

sampling carcases that were earmarked for human consumption.

\section{Material and methods \\ Ethics}

Mouflon are legally considered to be a game species in Germany and can be harvested by licensed hunters outside the closed season without special permission. No animals were killed with the aim of providing samples for this study. All hunted individuals were legally shot and made available to the authors.

\section{Sample collection}

We sampled a small free-living mouflon population in a $190 \mathrm{~km}^{2}$ study site in western Thuringia, comprising the southern part of the Eichsfeld and the western part of the Unstrut-Hainich administrative districts. While the size of the population has not formally been established, estimates by local hunters range from 150 to 250 individuals. Mouflons were translocated from the eastern Harz Mountains to the Eichsfeld district during the late 1970's [25], while further animals were illegally introduced to the Unstrut-Hainich district during the 1990's. Between 2011 and 2015, we collected blood from the heart of 138 legally hunted mouflons, corresponding to $84 \%$ of all animals hunted in that period. Samples were centrifuged for $10 \mathrm{~min}$ at $1000 \mathrm{~g}$ using an EBA 200 (Hettich, Tuttlingen, Germany) and sera stored at $-20{ }^{\circ} \mathrm{C}$ until analysis. We recorded the sex and age of each sampled animal as well as the year of collection. Based on horn size, males were classified as juveniles ( $\leq 1$ year), yearlings (1-2 years) or adults ( $\geq 2$ years), while females were similarly classified based on the dentition of the lower jaw $[20,21]$.

\section{Determination of antibodies to $T$.gondii}

Serum samples were tested for immunoglobulin G (IgG) antibodies against T.gondii with the modified agglutination test (MAT) using a commercial kit (Toxo-
Screen DA ${ }^{\circledR}$, bioMérieux, Lyon, France). Positive and negative controls were based on formalin-fixed tachyzoites as antigens. Each serum sample was tested at dilutions of 1:20, 1:400, 1:1600 and 1:3200. A cut-off titer of 1:20 was chosen to maximize both sensitivity and specificity of the test [8]. Among all the serological tests available, the MAT has been used extensively for the diagnosis of toxoplasmosis in both domestic and wildlife species because it is considered to be the most reliable to detect antibodies to T. gondii in animals, especially in latently infected animals [7].

\section{Statistical analysis}

The effect of sex, age class, and collection year on T. gondii seroprevalence was analyzed using a $\chi^{2}$ test performed in SPSS v.22 (SPSS Inc., Chicago, Illinois, USA). A $p$-value of $<0.05$ was chosen as the cut-off point for statistical significance. Odds ratios (ORs) and their 95\% confidence intervals $(95 \% \mathrm{Cls})$ were estimated to explore the strength of the association between the presence of T. gondii positivity and the explanatory variables.

\section{Results}

Antibodies to T. gondii were detected in 31 of the 138 (22.46\%, 95\% CI: 15.41-29.51) analyzed mouflons (Table 1). Positive results were recorded at titers between 1:20 (32.26\%), 1:400 (51.61\%), and 1:1600 (16.13\%). While seroprevalence was higher in males $(19 / 76 ; 25 \%)$ than females $(12 / 62 ; 19.35 \%)$, this difference was not significant $(p=0.429)$. Similarly, there was no significant difference in seroprevalence between collection years $(p=0.967)$. In contrast, there was a significant difference in seroprevalence between the different age classes $(p=0.002)$, with antibodies to T.gondii frequently present in adults in particular (Table 1).

\section{Discussion}

In the present study, we observed a relatively high seroprevalence of T.gondii $(22.46 \%)$ in a free-living 
German mouflon population. A similarly high value (24.4\%) was reported from captive Czech mouflons (based on an enzyme-linked immunosorbent assay, ELISA) [18]. Other studies that were also based on the MAT test reported lower prevalence values $<15 \%[1,2,10]$, while studies using different techniques for antibody detection reported even lower values $<10 \%[3,13]$.

The fact that we observed a relatively high frequency of T. gondii antibodies in a free-living herbivore suggests relatively high environmental contamination with oocysts. Rural habitats (forest, meadows, agricultural areas) like our study area can be exploited by the European wildcat (Felis silvestris silvestris) and/or feral domestic cats (Felis silvestris catus) [5,17], both of which have been reported to have a high serological prevalence of T. gondii antibodies in Germany $[11,22,24]$. Our study area is indeed located within the core distribution area of the wildcat in central Germany [14]. Altogether, 38.3\% of raccoons (Procyon lotor) sampled in the same study area were recently shown with a MAT test to be serologically positive for the protozoan [12].

Our results suggest that mouflons older than two years of age had a higher seroprevalence than younger animals, while there was no significant difference in seroprevalence depending on sex and year of sample collection. Infection with T.gondii is frequently more prevalent in adult than juvenile animals, since the cumulative likelihood of exposure to $T$. gondii increases with age and the antibodies have a lifelong persistence $[1,15]$. Since we did not observe a significant difference in seroprevalence between years, our results suggest that the environmental contamination with infective oocysts remained constant throughout the study. Almería et al. [1] found a significant difference in seroprevalence of T.gondii in wild ruminants in Spain between hunting seasons and explained this result by some study years being exceptionally dry, hindering the persistence of infective oocysts. In our case, it is likely that the rate of oocyst shedding from feral cats and wildcats remained constant, as did the environmental conditions during the study. Finally, as male and female mouflons live permanently in mixed herds, a difference in exposure risks between the two sexes is unlikely.

Concurrent with an increase in the number of hunted animals, there has been an increase in the consumption of mouflon meat in Germany. In many parts of Germany, including our study area, hunters produce home-made sausages derived from raw or undercooked meat, leading to a risk of food-borne transmission of T.gondii. Verma et al. [26] isolated viable T. gondii from two mouflons that were seropositive for the parasite and Calero-Bernal et al. [4] detected the presence of T. gondii with a polymerase chain reaction in 3 out of 12 tested mouflon (25\%). Further studies on different free-ranging mouflon populations are therefore required to assess infection levels in meat and the derived products intended for human consumption, and to assess the risk of transmission of the pathogen to humans.

\section{Conclusions}

This is the first epidemiological report of T.gondii prevalence in free-living mouflons in Germany. We show that $T$. gondii infection is prevalent in mouflons of all age ranges in a central German study population. This may represent a potential source of human infection with T. gondii.

\section{Conflict of interest}

The authors declare that they have no conflicts of interest in relation to this article.

\section{References}

1. Almería S, Cabezón O, Paniagua J, Cano-Terriza D Jiménez-Ruiz S, Arenas-Montes A, Dubey JP, GarcíaBocanegra I. 2018. Toxoplasma gondii in sympatric domestic and wild ungulates in the Mediterranean ecosystem. Parasitology Research, in press, DOI: 10.1007/s00436017-5705-6.

2. Aubert D, Ajzenberg D, Richomme C, Gilot-Reomont E, Terrier ME, de Gevigney C, Game Y, Maillard D, Gibert P, Dardé ML, Villena I. 2010. Molecular and biological characteristics of Toxoplasma gondii isolates from wildlife in France. Veterinary Parasitology, 171(3-4), 346-349.

3. Bárlová E, Sedlak K, Pavlik I, Literak I. 2007. Prevalence of Neospora caninum and Toxoplasma gondii antibodies in wild ruminants from the countryside or captivity in the Czech Republic. Journal of Parasitology, 93(5), 1216-1218.

4. Calero-Bernal R, Saugar JM, Frontera E, Pérez-Martín JE, Habela MA, Serrano FJ, Reina D, Fuentes I. (2015) Prevalence and genotype identification of Toxoplasma gondii in wild animals from southwestern Spain. Journal of Wildlife Diseases, 51, 233-238.

5. Doherty TS, Bengsen AJ, Davis RA. 2014. A critical review of habitat use by feral cats and key directions for future research and management. Wildlife Research, 41(5), 435446.

6. Dubey JP. 2009. History of the discovery of the life cycle of Toxoplasma gondii. International Journal for Parasitology, $39(8), 877-882$.

7. Dubey JP. 2010. Toxoplasmosis of animal and humans. $2^{\text {nd }}$ edn. CRC Press, Boca Raton, p. 1-313.

8. Dubey JP, Thulliez P, Weigel RM, Andrews CD, Lind P, Powell EC. 1995. Sensitivity and specificity of various serologic tests for detection of Toxoplasma gondii infection in naturally infected sows. American Journal of Veterinary Research, 56(8), 1030-1036.

9. EFSA. 2013. Scientific Opinion on the public health hazards to be covered by inspection of meat from farmed game. EFSA, 11(6), 3264, pp 181

10. Gauss CBL, Dubey JP, Vidal D, Cabezón O, Ruiz-Fons F, Vicente J, Marco I, Lavin S, Gortazar C, Almería S. 2006. Prevalence of Toxoplasma gondii antibodies in red deer (Cervus elaphus) and other wild ruminants from Spain. Veterinary Parasitology, 136(3-4), 193-200.

11. Hecking-Veltman J, Tenter AM, Daugschies A. 2001. Studien zur Parasitenfauna bei streunden Katzen im Raum Mönchengladbach. Praktischer Tierarzt, 82, 563-569. 
12. Heddergott M, Frantz AC, Stubbe M, Stubbe A, Ansorge H, Osten-Sacken N. 2017. Seroprevalence and risk factors of Toxoplasma gondii infection in invasive raccoons (Procyon lotor) in Central Europa. Parasitology Research, 116(8), 2335-2340.

13. Hejlícek K, Literák I, Nezval J. 1997. Toxoplasmosis in wild mammals from the Czech Republic. Journal of Wildlife Disease, 33(3), 480-485.

14. Hertwig ST, Schweizer M, Stepanow S, Jungnickel A, Böhle UR, Fischer MS. 2009. Regionally high rates of hybridization and introgression in German wildcat populations (Felis silvestris, Carnivora, Felidae). Journal of Zoological Systematics and Evolutionary Research, 47, 283-297

15. Hwang YT, Pitt JA, Quirk TW, Dubey JP. 2007. Seroprevalence of Toxoplasma gondii in mesocarnivores of the Canadian prairies. Journal of Parasitology, 93(6), 1370-1373.

16. Jones JL, Parise ME, Fiore AE. 2014. Neglected parasitic infections in the United Sates: toxoplasmosis. American Journal of Tropical Medicine and Hygiene, 90(5), 794-799.

17. Klar N, Fernández N, Kramer-Schadt S, Herrmann M, Trinzen M, Büttner I, Niemitz C. 2008. Habitat selection models for European wildcat conservation. Biological Conservation, 141(1), 308-319.

18. Lorencova A, Lamka J, Slany M. 2015. Toxoplasma gondii in wild ruminants bred in game preserves and farms with production destined for human consumption in the Czech Republic. Postravinarstvo, 9(1), 288-292.
19. Lutz W. 1997. Serologischer Nachweis von Antikörpern gegen Toxoplasma gondii und Leptospira bei Schwarzwild. Zeitschrift Jagdwissenschaft, 43(4), 283-287.

20. Piegert H, Uloth W. 2000. Das Europäische Mufflon. DSV Verlag GmbH, Hamburg, p. 1-258

21. Rieck W. 1968. Das Bestimmen des Muffelwildalters. Beiträge zur Jagd und Wildforschung, 6, 103-105.

22. Steeb S. 2015. Postmortale Untersuchungen an der Europäischen Wildkatze (Felis silvestris silvestris Schreber, 1777). PhD thesis, Justus Liebig Universität, Fachbereich Veterinärmedizin, Gießen, VVB Laufersweiler Verlag Gießen, pp 1-231.

23. Tackmann K. 1997. Seroprevalence of antibodies against Toxoplasma gondii in wild boars (Sus scrofa). In: EUR 18476-COST 820 Vaccines against animal coccidioses Annual report 1887. Luxembourg, Office for Official Publication of the European Communities, p. 167.

24. Tenter AM, Vietmeyer C, Johnson AM, Janitschke K, Rommel M, Lehmacher W. 1994. ELISAs based on recombinant antigens for seroepidemiological studies on Toxoplasma gondii infections in cats. Parasitology, 109(1), 29-36.

25. Telle R. 1979. Untersuchungen zu ausgewählten Problemen der Bewirtschaftung des Muffelwildes in der DDR. PhD thesis, Technische Universität Dresden, Fakultät Bau-, Wasser- und Forstwissenschaft, Dresden.

26. Verma SK, Su C, Dubey JP. 2014. Toxoplasma gondii Isolates from Mouflon Sheep (Ovis ammon) from Hawaii, USA. Journal of Eukaryotic Microbiology, 2014(0), 1-3.

Cite this article as: Heddergott M, Osten-Sacken N, Steinbach P, Frantz AC. 2018. Seroprevalence of Toxoplasma gondii in freeliving European mouflon (Ovis orientalis musimon) hunted in central Germany. Parasite 25, 21

Reviews, articles and short notes may be submitted. Fields include, but are not limited to: general, medical and veterinary parasitology; morphology, including ultrastructure; parasite systematics, including entomology, acarology, helminthology and protistology, and molecular analyses; molecular biology and biochemistry; immunology of parasitic diseases; host-parasite relationships; ecology and life history of parasites; epidemiology; therapeutics; new diagnostic tools.

All papers in Parasite are published in English. Manuscripts should have a broad interest and must not have been published or submitted elsewhere. No limit is imposed on the length of manuscripts.

Parasite (open-access) continues Parasite (print and online editions, 1994-2012) and Annales de Parasitologie Humaine et Comparée (1923-1993) and is the official journal of the Société Française de Parasitologie. 